W ostatnich latach ukazały się m.in. dwa interesujące druki bibliofilskie, na które warto zwrócić uwagę: szkic Andrzeja Skrzypczaka pt. W pogoni za białym krukiem. Kilka uwag o aukcjach antykwarycznych (Warszawa 2010) oraz katalog-przewodnik Marka Sosenki pt. Papierowe cudeńka, czyli niezwykły świat luksusowych papierów (Łomża 2011). Pierwszą pozycję wydano z okazji jubileuszu wieloletniego działacza Stowarzyszenia Księgarzy Polskich - dr. Andrzeja Skrzypczaka. Druk został wytłoczony w 99 numerowanych egzemplarzach według opracowania typograficznego wybitnego grafika Andrzeja Tomaszewskiego w Zespole Szkół Poligraficzno-Księgarskich w Krakowie.

Andrzej Skrzypczak, związany z Instytutem Informacji Naukowej i Studiów Bibliologicznych Uniwersytetu Warszawskiego, jest jednym z niewielu bibliologów zajmujących się tematyką księgarstwa, a szczególnie księgarstwa antykwarycznego. Jest aktywny na tym polu badawczym od lat 60. ubiegłego wieku. Warto tu wspomnieć wydaną w serii „Książki o Książce” pracę jego autorstwa Sennewaldowie ksiegarze i wydawcy warszawscy (Wrocław 1969) oraz wiele artykułów publikowanych w periodykach naukowych i branżowych. W tych ostatnich, głównie w „Księgarzu”, „Przeglądzie Księ-

\section{0 aukcjach, kolekcjach i cymeliach. Bibliofilskie gawędy Andrzeja Skrzypczaka i Marka Sosenki}

DOI: $10.12775 /$ TSB. 2013.009

garskim i Wydawniczym", a ostatnio w „Wiadomościach Księgarskich”, na bieżąco komentował w ciągu kolejnych lat aukcje antykwaryczne. Andrzej Skrzypczak to nie tylko nauczyciel akademicki i badacz, ale także społecznik, aktywny m.in. w środowisku księgarskim i bibliofilskim, rzeczoznawca i kolekcjoner. Jednym słowem - teoretyk i praktyk w jednej osobie.

Nieduża objętościowo książeczka pt. W pogoni za białym krukiem. Kilka uwag o aukcjach antykwarycznych $\boldsymbol{c h}^{1}$ to zajmująca, napisana ze swadą i pasją gawęda bibliofilska, zaopatrzona w aparat naukowy w postaci przypisów, w których zaprezentowano m.in. literaturę przedmiotu.

Autor skupił się na, najbardziej mu bliskich, czasach „Domu Książki” i nam współczesnych. Pierwszy rozdział pt. Początki aukcji antykwarycznych -

1 A. Skrzypczak, W pogoni za białym krukiem. Kilka uwag o aukcjach antykwarycznych, Warszawa: Stowarzyszenie Księgarzy Polskich 2010, 66 s. 
w zasadzie wbrew tytułowi - obejmuje dużo szerszy okres od XVI w. do 1945 r. i jest zakończony przeglądem opracowań z tego zakresu oraz wyliczeniem dość obfitej, choć często nieregularnej, czy wręcz efemerycznej prasy antykwarskiej. Następny rozdział pt. Powojenne aukcje antykwaryczne jest podzielony na kilka podrozdziałów, niestety znów nie do końca konsekwentnie: Epoka Domu Ksiq̨żki pierwsze aukcje bibliofilskie w latach 1948 i 1949 oraz organizowane przez Przedsiębiorstwo Państwowe „Dom Książki” w latach 1956-1989; Aukcje specjalistyczne - cztery imprezy z lat 1956-1986 (albumy, mapy i ryciny 1963; ekslibrisy - 1969, 1970; czasopisma - 1984); Efekty ekonomiczne (prowizje, ogólne wyniki aukcji); Notowania (przebicia i ich konteksty); Rekordy i książki najdroższe; Katalogi; Klientela. Drugi rozdział pt. Wspótczesne aukcje antykwaryczne jest zbudowany według zupełnie innego schematu i obejmuje podrozdziały: Lata 1990-2009; Warsztat informacyjno-bibliograficzny; Współpraca międzynarodowa; Internet - Allegro - eBay.

Pierwsze aukcje antykwaryczne w Europie odbyły się już w XVI w., na ziemiach polskich $\mathrm{w}$ XVII stuleciu - w Gdańsku; w wieku XVIII i XIX licytowano wielokrotnie także w Krakowie, Lwowie, Warszawie, Toruniu; organizatorami aukcji byli głównie księgarze i antykwariusze. Wyprzeda- wano w ten sposób całe kolekcje, ale również biblioteczne dublety. W XX w. do instytucji urządzających aukcje dołączyły towarzystwa bibliofilskie. W latach okupacji odbyło się kilka tajnych licytacji.

Dalsza historia rozpoczyna się od tużpowojennego epizodu pierwszych krakowskich i warszawskich aukcji bibliofilskich z roku 1948, po którym nastąpiła kilkuletnia przerwa. Jak wiemy, zlikwidowano w tym czasie prywatny ruch wydawniczy i księgarstwo, pozostawiając jedynie - mocno jednak ograniczane i szykanowane - antykwariaty, jednocześnie od $1951 \mathrm{r}$. tworząc dla nich państwową konkurencję. Po październikowym przełomie w nowym klimacie powstały dogodne warunki i Państwowe Przedsiębiorstwo „Dom Książki”, na wniosek Towarzystwa Miłośników Książki, w grudniu 1956 r. zorganizowało wreszcie swoją pierwszą aukcję. Licytację przeprowadził krakowski antykwariat przy ul. Brackiej 6. Od tego momentu coraz częściej odbywały się aukcje, głównie w Krakowie i Warszawie, ale również w innych miastach, gdzie funkcjonowały przodujące i profesjonalnie prowadzone antykwariaty naukowe. Aukcje antykwaryczne „Domu Książki” stały się szybko czymś w rodzaju święta antykwariatów i bibliofilów, które celebrowano z pompą. Zdarzały się wystawy i wykłady; wydawano druki okolicznościowe, ekslibrisy; te wydarzenia były 
obszernie komentowane $\mathrm{w}$ prasie lokalnej i branżowej. Aukcje podnosiły rangę placówki i jej pracowników, budowały prestiż, przynosiły także niemałe dochody.

Mimo że od 1956 r. organizowano coraz więcej aukcji, to jednak nie ustawały głosy krytyki, często nawiązujące do zideologizowanych wywodów pseudoksięgoznawców z lat stalinizmu o snobizmie kupujących i pogoni za zyskiem sprzedających. Wciąż trudno było pogodzić planową gospodarkę, „społeczną sprawiedliwość”, najróżniejsze racje wyższe z kolekcjonerską pasją i współzawodnictwem i żywiołowo nieraz kształtującymi się cenami. Andrzej Skrzypczak, dobrze pamiętający tamte czasy, zwrócił - i słusznie - uwagę na ówczesną specyfikę, liczne uwarunkowania - polityczne, prawne i ekonomiczne, jakie wpływały na rynek antykwaryczny, w tym także aukcje. Cenzura, wadliwa polityka wydawnicza i idące za tym coraz bardziej dotkliwe niedobory na rynku księgarskim, wreszcie specyficzny system walutowy i galopująca inflacja lat 80. - to rzeczywistość rynku antykwarycznego PRL.

Po 1989 r. nastąpiła odbudowa niezależnego ruchu wydawniczego i prywatnego księgarstwa, w tym również prywatnych antykwariatów. Wiele było w ciągu minionych lat inicjatyw, które zakończyły swoją działalność, często bardzo szybko; powstały jednak, utrzy- mały i rozwijają się takie profesjonalne firmy, jak Rara Avis i Wójtowiczowie w Krakowie czy warszawski Lamus, które są także liderami na rynku aukcyjnym. Polscy antykwariusze coraz odważniej i efektywniej działają na rynku międzynarodowym. Uwadze A. Skrzypczaka nie uszły też sprawy handlu książką w sieci; temu zagadnieniu są poświęcone ostatnie strony publikacji.

W ocenie minionego okresu dziejów polskiego księgarstwa trzeba zdecydowanie oddzielić chore i z gruntu nienormalne warunki, $w$ jakich przyszło pracować księgarzom i antykwariuszom, od efektów ich działalności i roli, jaką odegrali. Co więcej, w tej ocenie nie może umknąć uwadze, że to właśnie przeważnie ci ludzie odbudowali w sprzyjających warunkach wolny, prywatny rynek książki. Andrzej Skrzypczak umiejętnie wskazał mankamenty i patologie tamtych lat (m.in. rozbudowaną centralną biurokrację przedsiębiorstwa oraz - z reguły przez nią właśnie zaprowadzane - szkodliwe regulacje i przepisy utrudniające obrót antykwaryczny), ale równocześnie uchwycił wagę i znaczenie sieci antykwariatów „Domu Książki”, niesprowadzające się tylko do samych aukcji. Faktem też jest to, że dużo zrobiono w tym czasie w zakresie podnoszenia kwalifikacji kadry; dzisiaj w warunkach wolnego rynku antykwariusz sam musi o to zadbać. Sukces wielu 
firm, profesjonalizm, z jakim spotykamy się chociażby we współczesnych katalogach, pokazuje jednak, że są tacy, którzy potrafią sprawnie działać bez pomocy biurokratycznych struktur.

$W$ pogoni za białym krukiem to wydawnictwo jubileuszowe, którym uświetniono 70. rocznicę urodzin A. Skrzypczaka. Złożyły się na nie teksty, jak się wydaje, w części już wcześniej publikowane. Zdradzają to w pewnym sensie pierwsze słowa drugiego rozdziału, w których autor odwołuje się do publikowanego w $2008 \mathrm{r}$. w „Wiadomościach Księgarskich” tekstu noszącego identyczny z pierwszym rozdziałem tytuł (s. 44). Można przypuszczać, że stąd zapewne wzięły się pewne redakcyjne nieścisłości, zasygnalizowane już powyżej; z tego powodu zabrakło w przywoływanej literaturze przedmiotu pięknej książki Iwony Imańskiej pt. Toruńskie aukcje książek w XVIII wieku (Toruń 2007). Szkoda, staranniejsza redakcja mogła podnieść walory tej, skądinąd ciekawej, książeczki. Szkoda też, że nie zadbano o ISBN, którego brak w istotny sposób ogranicza „karierę” publikacji. Również staranne opracowanie graficzne Andrzeja Tomaszewskiego niezbyt dobrze wypada w wykonaniu Zespołu Szkół Poligraficzno-Księgarskich w Krakowie - po jednym przeczytaniu broszura rozpada się...

Niemniej jednak $W$ pogoni za białym krukiem. Kilka uwag o aukcjach an- tykwarycznych Andrzeja Skrzypczaka to książka ważna i - jak na razie - jedyna w polskiej literaturze przedmiotu. Bibliofilska gawęda, pełna wdzięku i polotu, ale równocześnie inspirująca do dalszych badań, zawierająca wiele cennych informacji, spostrzeżeń i refleksji, które przewijać się będą - jestem o tym przekonany - w dalszych opracowaniach dotyczących rynku antykwarycznego. Piszący te słowa wiele już skorzystał z tej i innych publikacji tego zasłużonego badacza i bibliofila.

Druga z omawianych pozycji to Papierowe cudeńka, czyli niezwykły świat luksusowych papierów ${ }^{2}$, katalog wystawy - w opracowaniu Marka Sosenki - zorganizowanej w lutym 2011 r. w Muzeum Północno-Mazowieckim w Łomży, w ramach której zaprezentowano eksponaty pochodzące z prywatnych zbiorów rodziny Sosenków - kolekcjonerów krakowskich, współpracujących z łomżyńską placówką od ponad 16 lat.

Marek Sosenko jest jednym z najbardziej znanych, cenionych i - przede wszystkim - wszechstronnych polskich kolekcjonerów, a swoimi zainteresowaniami obejmuje (z wielkim powodzeniem!) wszystkie niemal dziedziny kultury materialnej. Kolekcjonerską

2 M. Sosenko, Papierowe cudeńka, czyli niezwykły świat luksusowych papierów, Łomża: Muzeum Północno-Mazowieckie 2011, 57 s., ISBN 978-83-87108-40-3, ISBN 978-83-60255-54-4 („Kolekcje Sosenków”, nr 3). 
pasję, realizowaną z udziałem rodziny, łączy umiejętnie z działalnością badawczą i popularyzatorską - organizuje wystawy, przygotowuje w oparciu o swoje zbiory i wydaje opracowania, katalogi, wreszcie - umożliwia także innym badaczom korzystanie z nich. Wyliczanie publikacji, w których w mniejszym i większym stopniu posłużono się obiektami z kolekcji Sosenków, zajęłoby wiele miejsca.

Tytułowe „papierowe cudeńka” to - można rzec śmiało - danie specjalne z kolekcji Sosenków obejmujące głównie drobne druki, akcydensy z XIX i początku XX w. Drobiazgi, na które nie zwracali przez lata uwagi bibliotekarze i muzealnicy, a które stały się z czasem nieosiągalnymi rzadkościami. Możemy je oglądać często właśnie dzięki hobbystom, zbieraczom, takim jak M. Sosenko. Wybrane obiekty z jego kolekcji dają pojęcie o ich bogactwie i różnorodności, pokazują także mało eksploatowane, a jakże ciekawe i intrygujące obszary badawcze bibliologii.

Ten swego rodzaju katalog-przewodnik otwierają dwa rękopisy: dobrze zachowane, pergaminowe dokumenty: pierwszy wystawiony przez króla Zygmunta Starego w 1519 r., drugi podpisany przez cesarza Austrii Leopolda I Habsburga w 1680 r. (s. 13), oraz trzy listy - Joachima Lelewela (1861), Cypriana Kamila Norwida (1863) i Józefa Ignacego Kraszewskiego (1864) (s. 14).
Legendarna już kolekcja pocztówek i listów M. Sosenki liczy ponad 700 tys. egzemplarzy, wśród których znajdują się prawdziwe cymelia, jak list $\mathrm{z}$ „czarną pensówką" z wizerunkiem królowej Wiktorii datowany 17 marca 1841 r. (s. 15) czy pierwsze znaczki i karty pocztowe z ziem polskich (s. 16). Z pocztowych eksponatów na uwagę zasługują także sztychowane i kolorowane akwarelą papiery listowe $\mathrm{z}$ widokami Berlina z lat 30. XIX w. (s. 36), polskie telegramy patriotyczne z końca tego stulecia (s. 30) oraz wykwintne, secesyjne pocztówki (s. 26-27).

Szczególnie bogato prezentują się najrozmaitsze drobne druki i akcydensy. Bileciki życzeniowe - kunsztownie „dekorowane aplikacjami ze złoconej, tłoczonej i sztancowanej galanterii umieszczonej na rozpiętym tiulu" (s. 17), wykrawane, tłoczone i złocone, przypominające koronkowe serwetki (s. 18). Bileciki mechaniczne, „które po przesunięciu odpowiedniej dźwigni zmieniały ilustrację" i scenki kulisowe (s. 19-21). Święte obrazki (s. 24-25). Premie i dodatki do wyrobów czekoladowych i kawy - wielobarwne, secesyjne alegorie kwiatów i przypraw (s. 22-23). Znaki kwestarskie, nieraz wyjątkowej urody pamiątki po licznych w XIX i pierwszej połowie $\mathrm{XX}$ w. akcjach charytatywnych. Uderzają swoją wymową szczególne takie hasła, jak: „Tanie Kuchnie dla Inteligencji”, „Sekcja Zwalczania Żebrac- 
twa”, „Pogotowie Głodowe dla Chorych Dzieci”, „Biuro Informacji o Nędzy Wyjątkowej” czy „Towarzystwo Niesienia Pomocy Biednym Rosjanom"... (s. 28-29). Zalepki - nieraz bardzo okazałe naklejki służące do zabezpieczania dokumentów (s. 38). Rachunki i papiery firmowe, zdobione nierzadko pięknymi rycinami i bogatym liternictwem (s. 37). Karty menu - firmowe i prywatne, pyszne i smakowite także w edytorskim znaczeniu tych słów (s. 39). Karneciki balowe pań, często bardzo wymyślne, w których wpisywali się kolejni partnerzy taneczni (s. 54). Losy loterii - okazałe i bogato ilustrowane (s. 40-41). Dawne etykiety, zawsze piękne, a niekiedy intrygujące, jak „Fluid przeciw podagrze”, „Jad pluskowy (sic!). Najpewniejszy środek na pluskwy” czy „Perski proszek przeciwko owadom” (s. 52-53), w tym także świetnie zachowane przejęte - jak pisze M. Sosenko - „po zlikwidowanej krakowskiej piekarni” nalepki na pierniki (s. 44-45). Dyplomik pamiątkowy - „Dowód udziału w założeniu Szkoły Praktycznej Gospodarstwa Wiejskiego w W. X. Krakowskim" z 1860 r. (s. 55). Wreszcie wizytówki, niektóre zwracają uwagę kunsztownym ornamentem (s. 50-51).

Na koniec wypada wyróżnić scrapsy, które - jak czytamy we wstępie - „nie mają swojego odpowiednika w języku polskim”. Były to „wycinane, chromolitografowane, wytłaczane, złocone i lakierowane miniaturowe obrazeczki, którymi ozdabiano bileciki życzeniowe i wizytowe, zeszyty szkolne, pamiętniki, a w końcu same albumy, specjalnie na ten cel wykorzystywane" (s. 6). W książce zostały zaprezentowane kompozycje z epoki ze scrapsami, wykorzystujące także zasuszone rośliny (s. 46-49). Warto przy tej okazji zwrócić uwagę na dostępne na polskim rynku „wyklejanki”, przypominające właśnie co żywo angielskie scrapsy ${ }^{3}$. Niestety, autorzy najnowszego Uniwersalnego słownika języka polskiego nie odnotowali jeszcze tego znaczenia wyrazu4.

Ponadto w książce znalazły się także wybrane luksusowe oprawy książek (s. 31), ozdobne okładki nut z końca XIX w. (s. 42-43), kalendarze (s. 32), kilka ekslibrisów (s. 35) oraz przedwojenna gra planszowa „Podróż samochodem po Polsce” (s. 56).

Walorem omawianej publikacji są przede wszystkim starannie dobrane, wykonane i wydrukowane ilustracje. Papierowe cudeńka przynoszą sporo

3 Tego rodzaju wyklejanki, książeczki z nalepkami produkuje np. wydawnictwo Pasja oraz Colgraf z Inowrocławia. Ksiq̨żeczki edukacyjne z nalepkami [on-line]. Pasja Wydawnictwo Colgraf [dostęp 31 marca 2013]. Dostępny w World Wide Web: http://www.ksiazeczki.pl/index. php?go=ksnalep.

4 „Wyklejanka pot. «obrazek powstały z naklejonych na papierze lub kartonie kawałków kolorowego papieru, tkanin itp.; naklejanka»". Por. Uniwersalny słownik języka polskiego, t. 4: T-Z, pod red. S. Dubisza, Warszawa 2003, s. 604. 
ciekawego materiału, często unikatowego. Marek Sosenko prowadzi nas po swojej łomżyńskiej wystawie ze znawstwem i swadą, w kolejnych miniwykładach charakteryzuje poszczególne grupy obiektów, zwraca uwagę na istotne szczegóły, podkreśla wagę detali. Całości dopełnia obszerna bibliografia przedmiotu.

\section{Grzegorz Nieć}

Instytut Informacji Naukowej i Bibliotekoznawstwa Uniwersytetu Pedagogicznego im. KEN w Krakowie
$P$

rzemiany dokonujące się w systemie komunikacji naukowej, spowodowane jej dynamicznym rozwojem, wymuszały na przestrzeni wieków tworzenie nowych narzędzi, służących ciągłemu jej udoskonalaniu. Szczególne miejsce w tym systemie zajęły czasopisma naukowe i popularnonaukowe. Te pierwsze, założone w połowie XVII w., stały się - obok książki drukowanej komplementarnym kanałem przekazywania wiedzy naukowej. Miały one m.in. przekazywać ludziom nauki wiadomości o aktualnie prowadzonych badaniach i najnowszych osiągnięciach, a także ułatwiać dostęp do potrzebnych im informacji w sytuacji odczuwanego już wówczas jej nadmiaru. Natomiast w wersji popularnonaukowej, funkcjonującej w systemie komunikacji społecznej od XVIII w., czasopisma miały informować szersze kręgi społeczeństwa o postępie w nauce oraz służyć jej upowszechnianiu i popularyzacji. Ulegając pewnym przemianom i udoskonaleniom, stały się aż do czasów mediów elektronicznych istotnym

\section{Barbara Centek, Naukowe i popularnonaukowe czasopisma Lubelszczyzny 1944-1989, Warszawa: Tetragon 2012, 332 s., il., ISBN 978-83-930318-0-1}

DOI: $10.12775 / T S B .2013 .010$

narzędziem służącym komunikowaniu się uczonych między sobą, a także z innymi grupami społecznymi.

Mimo że od zaistnienia na rynku wydawniczym czasopism naukowych mija już czwarty wiek, to nadal jeszcze nie wszystkie były przedmiotem naukowej refleksji. Stąd też zarówno w opracowaniach z zakresu historii nauki, jak i prasoznawstwa ciągle napotykamy białe plamy. Dotyczy to m.in. badań poświęconych problematyce naukowej i popularnonaukowej prasy regionalnej, genezie jej powstawania, przemianom i przekształceniom oraz jej roli w systemie komunikacji naukowo-społecznej. Tę lukę stara się wypełnić książka autorstwa Barbary 